\title{
Determination of optimal prey for rearing the Tropical Gar Atractosteus tropicus (Lepisosteiformes: Lepisosteidae)
}

\author{
Luis Humberto Escalera-Vázquez ${ }^{1 *}$, Omar Domínguez-Domínguez²,
} Eduardo Molina-Domínguez ${ }^{2}$, S.S.S. Sarma ${ }^{3} \&$ S. Nandini ${ }^{3}$

1. CONACyT- Instituto de Investigaciones sobre los Recursos Naturales, Universidad Michoacana de San Nicolás de Hidalgo, avenida Juanito Itzícuaro S/N, Nueva Esperanza, 58330 Morelia Michoacán, México; 1hescalera@gmail.com

2. Laboratorio de Biología Acuática, Facultad de Biología, Universidad Michoacana de San Nicolás de Hidalgo, edificio R, planta baja, Ciudad Universitaria, Morelia, Michoacán, México; goodeido@yahoo.com.mx, danubio22@yahoo.com

3. Laboratorio de Zoología Acuática, División de Investigación y Posgrados, Universidad Nacional Autónoma de México, Campus Iztacala, Av. de Los Barrios s/n Los Reyes, CP 54090, Tlalnepantla, Estado de México, México; sarma@unam.mx,nandini@unam.mx

* Correspondence

Received 20-XI-2017. Corrected 02-V-2018. Accepted 11-VI-2018.

\begin{abstract}
Larval feeding studies of both ornamental and consumable fish species are important for formulating successful management, and culture strategies for conservation purposes. In the present study, we evaluated prey selectivity for the tropical gar Atractosteus tropicus in the larval stage (first 8 weeks) using the zooplankton Artemia fransiscana, Daphnia pulex and Moina macrocopa as prey following the hypothesis that prey selection of the fish species is related not only to prey species preferences but to the difference in prey densities present in the environment. Functional responses were tested at prey densities of $0.2,0.5,1.0,2.0,4.0$ and 8.0 ind. $\mathrm{mL}^{-1}$ and analyzed using Manly's $\alpha$. For prey selectivity, we used the three zooplankton species at three different densities. In these two experiments the fish larvae were allowed to feed for $45 \mathrm{~min}$. To quantify feeding behavior (encounters, attacks, captures, ingestions, rejections) we used a density of 1 ind. $\mathrm{mL}^{-1}$ using each prey species based on 10 minutes of direct observation. Our results showed a functional response Type II for $A$. tropicus preying mostly on A. franciscana and M. macrocopa. The Manly's $\alpha$ index showed that M. macrocopa and A. franciscana are the most preys selected. The values for encounters for the three prey species were relatively constant during the eight weeks. Encounter values for the cladocerans were low in comparison to A. franciscana; however, high success in capture and ingestion was observed for all prey species used. Our results from the functional response experiments supports the hypothesis that $A$. tropicus is an active predator presenting a functional response of a carnivorous fish and the shift in prey selection suggests that even at low prey availability, A. tropicus is able to manipulate and feed on zooplankton of wide range in size. Also, according to our results, we suggest the use of a mix of $A$. franciscana and M. macrocopa to feed A. tropicus in culture systems in concentrations $\approx 2$ ind. $\mathrm{mL}^{-1}$ during the first 3 weeks of age and then shift to M. macrocopa from the 4 week. Our results, in conjunction with studies on the survivorship of the juveniles would aid in conservation efforts and improve the production of gars in aquaculture. Rev. Biol. Trop. 66(3): 1018-1033. Epub 2018 September 01.
\end{abstract}

Key words: functional response; planktonic prey; prey selection; tropical gar.

The ecological and ethological aspects in the larval feeding of fishes have received attention from aquatic ecologists and fishery biologists (Lazarro, 1987; Rao, 2003). Larval feeding for carnivorous fishes is one of the key aspects for the commercial aquaculture and one of the greatest challenges in accomplishing fish production in controlled culture systems (Zambonino \& Cahu, 2007; Nguyen, Reinertsen, Wold, Tran, \& Kjørsvik, 2010). In North America, Central America and Cuba, the overfishing of gars is one of the main factors related to 
its population decline (Mendoza, Aguilera, \& Ferrara, 2008). The increasing demand among gar producers, local fisheries and aquarists, requires improved food supply for fish larvae in controlled culture systems for exploitable native species. For instance, in Southeastern Mexico, an increasing demand for the tropical gar, Atractosteus tropicus (Gill, 1863), due to a high local consumption, sport fishing, handicrafts and cultural value, requires improvement in ex situ production (Mendoza, Aguilera, Rodriguez, González, \& Castro, 2002). Unfortunately, in Mexico, aquaculture techniques have been introduced to the country to cultivate mainly non-native species (e.g. Oreochromis spp., Micropterus salmoides, Cyprinus carpio), which in some cases pose a potential risk for native aquatic fauna through predation, competition and niche overlap (Zambrano, Perrow, Aguirre-Hidalgo, \& Macías-García, 1999; Tapia \& Zambrano, 2003; Domínguez-Domínguez, Pérez-Ponce de León, Martínez-Meyer, \& Zambrano, 2006; Córdova-Tapia, Contreras, \& Zambrano, 2014).

Recently, important efforts have been focused on developing biotechnology for the culture and reproduction in controlled conditions of A. tropicus in Southeast Mexico, not only for the mass production of food, but also for the conservation and reestablishment of wild populations by artificial introductions (Márquez-Couturier et al., 2006). Many commercially important fish are oviparous and the hatchlings are independent of external diet as long as the yolk persists; however, due to rapid growth and development in oviparous fish, this source of nutrition usually lasts only 2-4 days (Lazarro, 1987; Morales-Ventura, Nandini, \& Sarma, 2004). For effective feeding by larval fish, zooplankton prey should be available at a certain critical density and size, in order to promote survivorship and growth at early stages (Juanes, 1994; Cunha \& Planas, 1999). This can vary depending on the larval age and the natural feeding habits of the species in turn (Laurel, Brown, \& Anderson, 2001). In this context, ecological and ethological aspects of fish feeding are useful in preventing larval mortality, permitting an increase in growth rate, reducing cannibalism and increasing the survivorship of the larvae in reintroduction programs (Colgan, Brown, \& Orsatti, 1986; Katavic, Jug-Dujakovic, \& Glamuzina, 1989; Atencio-García \& Zaniboni, 2006). Although food and feeding aspects of many important fish in aquaculture such as catfish, carps and trouts have received considerable attention and information about feeding habits and feeding behavior of larvae of commercial carnivorous native fishes, is unknown or less available (Jhingran, 1991; Dutta, 1996).

The tropical gar presents carnivorous larval stages and feeding and nutrition in controlled conditions is critical to prevent high mortalities (Márquez-Couturier et al., 2006). The use of zooplankton as live food increases and improves fish production (Katavic et al., 1989; Atencio-García \& Zaniboni, 2006); however, even when some ethological aspects of feeding behaviour are well-documented, the supply of adequate live food could be difficult and expensive (Sarma, López-Rómulo, \& Nandini, 2003). Thus, to develop proper diets considering feeding aspects, especially during the early stages of larval development, can reduce mortality, enhance growth of fish larvae and reduce production costs in the culture of carnivorous tropical native fish. Therefore, the goal of the present work was to determine the optimal prey species and densities for rearing the tropical gar A. tropicus in the early larval stages (first 8 weeks), quantifying the prey selection and determining the feeding behavior and functional response using three zooplankton species as prey; following the hypotheses: i) A. tropicus will show a carnivorous functional response since external feeding is present; ii) the prey selection of this fish species is related not only to prey species but also to differences in prey densities in the environment; and iii) fish will handle and feed on prey more successfully with increasing age.

\section{MATERIAL AND METHODS}

Experimental conditions: Fish eggs were donated from the Aqua-Pet fish farm located 
in the State of Tabasco, Mexico. The spawning was not induced and $98 \%$ of eggs were fertilized obtaining 125 eggs of A. tropicus which were maintained in two aquaria of 50 L (62-63 eggs per aquarium) with constant aeration and temperature controlled by 300 W heaters (AQUATOP, Model GH-300, Brea, CA, USA). Experimental conditions and results are presented as mean \pm standard error. Daily, temperature $\left(27 \pm 0.18{ }^{\circ} \mathrm{C}\right)$, dissolved oxygen $\left(7.5 \pm 0.05 \mathrm{mgL}^{-1}\right)$ and $\mathrm{pH}(8.2 \pm 0.05, \mathrm{~N}=10$ aquaria) were measured in each aquarium using a laboratory thermometer, an oximeter (YSI, Model 51B, Yellow Springs, OH, USA) and a $\mathrm{pH}$ meter (CONDUCTRONIC, ModelPC18, Puebla, Puebla, Mexico); weekly, $20 \%$ of the water in each aquarium was replaced using a syphon vacuum cleaner (PEN-PLAX, 16 inch gravel vac, Hauppauge, NY, USA). In all 106 hatched larvae were obtained and placed as stock in two aquaria of $250 \mathrm{~L}$ maintained under the same conditions as the eggs and subjected to 12:12 light:dark hours photoperiod using fluorescent lamps until complete yolk absorption and exogenous feeding was needed. In each stocking aquarium $(\mathrm{N}=38)$, temperature (26.5 $\left.\pm 0.2^{\circ} \mathrm{C}\right), \mathrm{pH}(8.0 \pm 0.01)$ and dissolved oxygen $\left(7.1 \pm 0.02 \mathrm{mgL}^{-1}\right)$ were measured every third day along the eight weeks of the experiment using the instruments mentioned above.

For experiments as well as for routine feeding of the larvae, we cultured separately three species of zooplankton (2 cladocerans and 1 branchiopod). Daphnia pulex (1 500 $\pm 0.65 \mu \mathrm{m}, \mathrm{N}=80$ ) and Moina macrocopa (1 $000 \pm 0.6 \mu \mathrm{m}, \mathrm{N}=80$ ) were cultured in 10 L transparent plastic bottles with EPA medium (Anonymous1985) in $1 \mathrm{~L}$ of distilled water at $25{ }^{\circ} \mathrm{C} \pm 0.16(\mathrm{~N}=24)$ and $\mathrm{pH} 7.9 \pm 0.02(\mathrm{~N}=$ 24). Artemia franciscana $1700 \pm 0.62 \mu \mathrm{m}, \mathrm{N}=$ 80 ) was cultured in eight $200 \mathrm{~L}$ plastic pools, at salinity of $45 \mathrm{gL}^{-1}$ temperature $26.05 \pm 0.34{ }^{\circ} \mathrm{C}$ and $\mathrm{pH} 8.2 \pm 0.03(\mathrm{~N}=24)$. Once a week, 10 individuals of each zooplankton species were randomly collected from the culture bottles to obtain the size (length) using a micrometer 10:100 ( 8 weeks $\mathrm{x} 10$ individuals $=\mathrm{N}=80$ per species). The culture medium for cladocerans was replaced $100 \%$ every three days, and for the branchiopod $20 \%$ of the total water in each pool was replaced every week. For zooplankton culture, the single-celled green alga Chlorella vulgaris was cultured using Bold's basal medium (Borowitzka \& Borowitzka, 1988) in 10 transparent containers of $2 \mathrm{~L}$ maintained with continuous aeration and fluorescent illumination. Temperature and $\mathrm{pH}$ for this culture was measured once a week in each bottle $(25$ ${ }^{\circ} \mathrm{C} \pm 0.11, \mathrm{pH} 7.9 \pm 0.01, \mathrm{~N}=80$ ). The green alga was given at concentration of $0.6 \times 10^{6}$ cells $\mathrm{mL}^{-1}$ every day as food for zooplankton. For feeding zooplankton, we routinely harvested the log phase algae, centrifuged at $4000 \mathrm{rpm}$ for 5 minutes and re-suspended in moderately hardwater EPA medium. Algal density was quantified using a hemocytometer and diluted to the desired density for feeding zooplankton.

The experiments were conducted during the first eight weeks of larval stage, starting since the first exogenous feed (4-5 days after hatching) using fish larvae of known age. Prior to each experiment, all larvae were starved for 2 hours following Tilseth and Ellertsen (1984) in separated aquaria with pre-filtered water (50 $\mu \mathrm{m}$ mesh). In order to reduce stress on the fish larvae, for each experiment we filtered preconditioned (water in which A. tropicus individuals were maintained) water with a $50 \mu \mathrm{m}$ mesh to use in the experimental vessels $(150 \mathrm{~mL}$ plastic vessels; dimensions: length $8 \mathrm{~cm}$, width 5.5 $\mathrm{cm}$, height $3.5 \mathrm{~cm}$ ) and filled with $25 \mathrm{~mL}$ of EPA and $25 \mathrm{~mL}$ of pre-filtered water and after 15 min, prey density was added according to the specific experiment. Temperature was measured in each vessel after each trial using a laboratory thermometer. Given the salinity conditions in the A. franciscana culture, this species was separated from the experimental containers $30 \mathrm{~min}$ before to start each experiment using plastic sieves (2000 $\mu \mathrm{m}$ mesh size $)$ and rinsed carefully with tap water to avoid salinity conditions in the experimental vessels. In all experiments, prey species were counted using a Pasteur micropipette until prey density was reached according each experimental design. All the different treatments for each 
experiment were conducted with five replicates and one fish per replicate. Standard length $\left(\mathrm{L}_{\mathrm{s}}\right)$, gape width $\left(\mathrm{G}_{\mathrm{W}}\right)$ and gape length $\left(\mathrm{G}_{\mathrm{L}}\right)$ of fish were measured to the nearest $\mathrm{mm}$ weekly from 15-18 larvae (total $\mathrm{N}=131$ ) taken at random during the eight weeks of the experiment using a digital calliper (TRESNA $®$ EC16; Guangxi, China); $G_{W}$ was measured every time at the half of the $\mathrm{G}_{\mathrm{L}}$.

Functional response: In order to study the functional response of A. tropicus, we selected one fish larva at random into each of the experimental vessel; the branchiopod and cladoceran species were offered independently at six different densities (Table 1). The fish larvae were allowed to feed for $45 \mathrm{~min}$ and after the feeding period, were carefully removed and returned to the culture aquaria. The remaining zooplankton in the experimental vessels were fixed with $10 \%$ formalin and quantified using a stereo microscope at $20 \mathrm{X}$ magnification. The number of prey consumed by each larva was determined as the difference between the initial and the final prey count.

The functional response describes the prey consumption rate of a predator as a function of the density of a given prey. In biological terms, the functional response Type I is found in passive predators, where the number of prey caught is proportional to prey density, thus prey mortality is related to constant predation; in Type II the search rate of prey is constant, and prey mortality declines in relation to prey density; and Type III is related to predators that increase the search activity of prey related to the prey density (Krebs \& Davies, 1993). Therefore, functional response curves were analyzed using the model of Holling (1966) and calculated by the equation in Lampert and Sommer (1997) described in table 1.

To distinguish between Type I, II and III functional responses, we used the procedures described by Trexler, McCulloch, and Travis (1988), which involves the logistic regression of the proportion of prey eaten related to the density of prey offered (Table 1). We used
Analyses of Variance (ANOVA) to test for differences between the means of prey consumption at the asymptote of the functional response curves and the maximum prey consumption $\left(\mathrm{F}_{\max }\right)$ in relation to the age of the fish larvae and prey species offered.

Prey selection: For determining prey selection, we used the zooplankton prey in three different densities based on Greene (1983), Nandini and Sarma (2000) and Gallardo-Alanis, Sarma, and Nandini (2009) (Table 1). The fish larvae were allowed to feed for $45 \mathrm{~min}$ and thereafter they were removed. The number of prey consumed by each larva was determined as the difference between the initial and the final prey count. We also randomly dissected out 2-3 guts per week of fish larvae to make sure that the number of prey consumed tallied with the counts. Prey selectivity was calculated following Manly's $\alpha$ (Krebs \& Davies, 1993) and Two-way ANOVA was performed to test for statistical differences among consumption of prey types (Factor A) and densities (Factor $\mathrm{B}$ ), and post hoc analysis for paired comparisons was used (i.e. Tukey-Kramer HSD).

Feeding behaviour: For experiments of feeding behaviour, the density of prey used was 1 ind. $\mathrm{mL}^{-1}$ for cladocerans as well as for the branchiopod. We quantified the components of feeding behaviour (encounter, attack, capture, ingestion, prey rejection and prey escapes) based on 10 minutes of direct observation of a total of 15 fish larvae placed individually in the experimental vessels using a lamp with a magnifying glass and following Greene (1983), over the eight weeks of the experiment. We considered an encounter as the number of occasions in which the predator recognized its prey. This was evident by changes in the swimming behaviour and visual contact of the fish larvae and the prey. Attacks were the number of assaults made by predator towards the prey with intent to capture it. Capture is considered when the prey is in the mouth of predator; in this moment, the prey can be ingested or escape from the predator's mouth. The ingestion and 


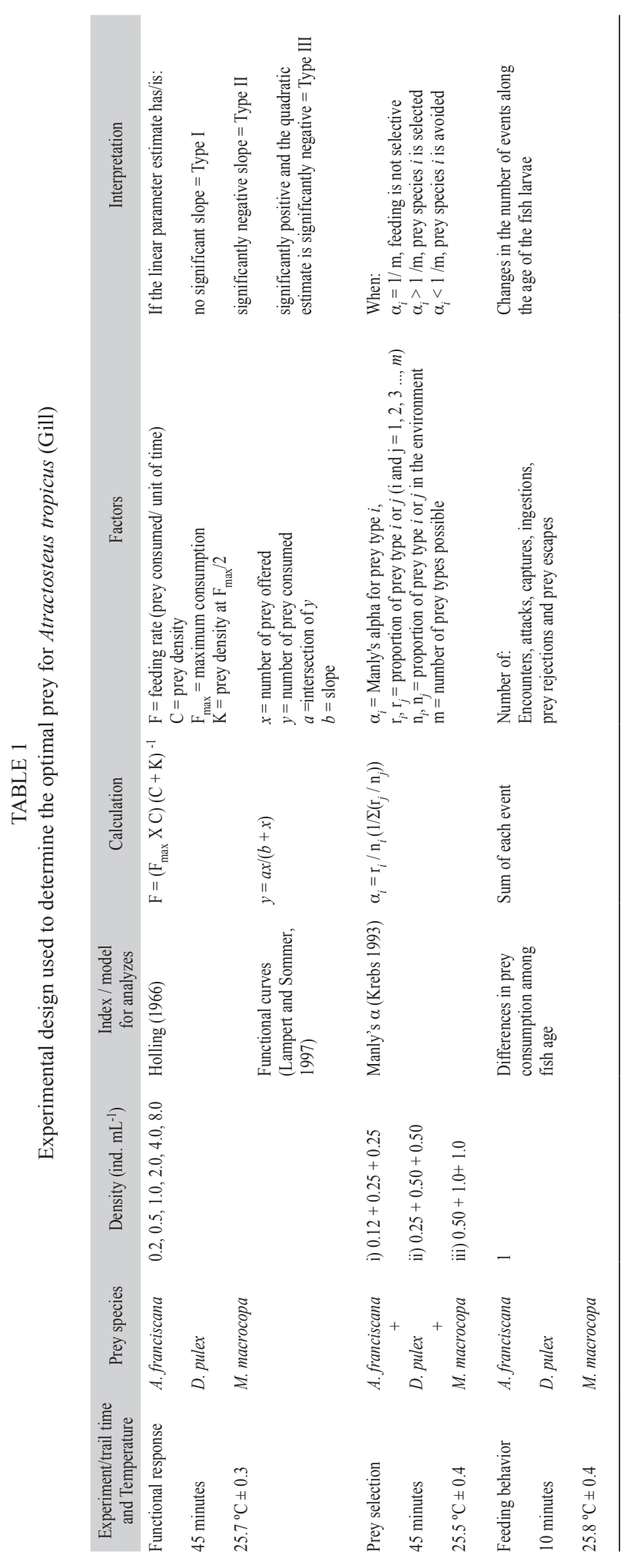


escape are easily differentiated by the fish and prey movements.

Differences in prey consumption were tested using ANOVA and post hoc analysis for paired comparisons (i.e. Tukey-Kramer HSD). Relations of the $L_{s}$ to $G_{W}$ and $G_{L}$ were calculated using lineal regression models. Data analyses for all the experiments were performed with the libraries stats and MASS (Venables \& Ripley, 2002) using the statistical computer environment R 3.2.0 (R development core team, www.r-project.org).

\section{RESULTS}

Functional response: The functional response curves of $A$. tropicus larvae at the different ages showed an approximation to the asymptote when more than 4 ind. $\mathrm{mL}^{-1}$ (Fig. 1, Fig. 2 and Fig. 3). Overall, a Type II functional response with any prey species offered was present as observed in the significantly negative slopes (Table 2). The average of the maximum consumption during the eight weeks of $A$. franciscana $(105 \pm 18.73)$ and M. macrocopa

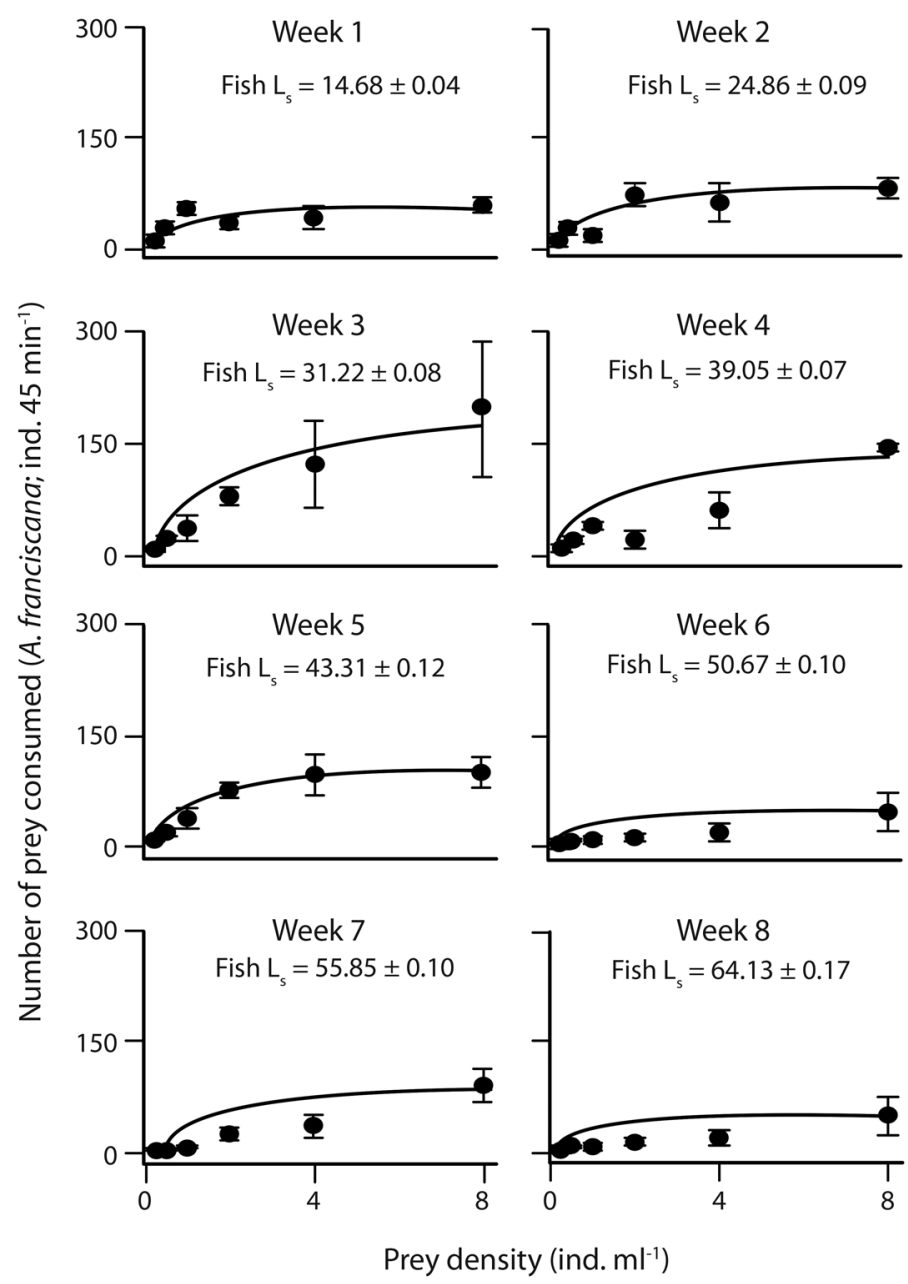

Fig. 1. Functional response of larval Atractosteus tropicus (Gill) based on the model of Holling using A. franciscana as prey. Each point represents the mean $\pm \mathrm{SE}$, and $\mathrm{L}_{\mathrm{s}}=$ fish standard length. 


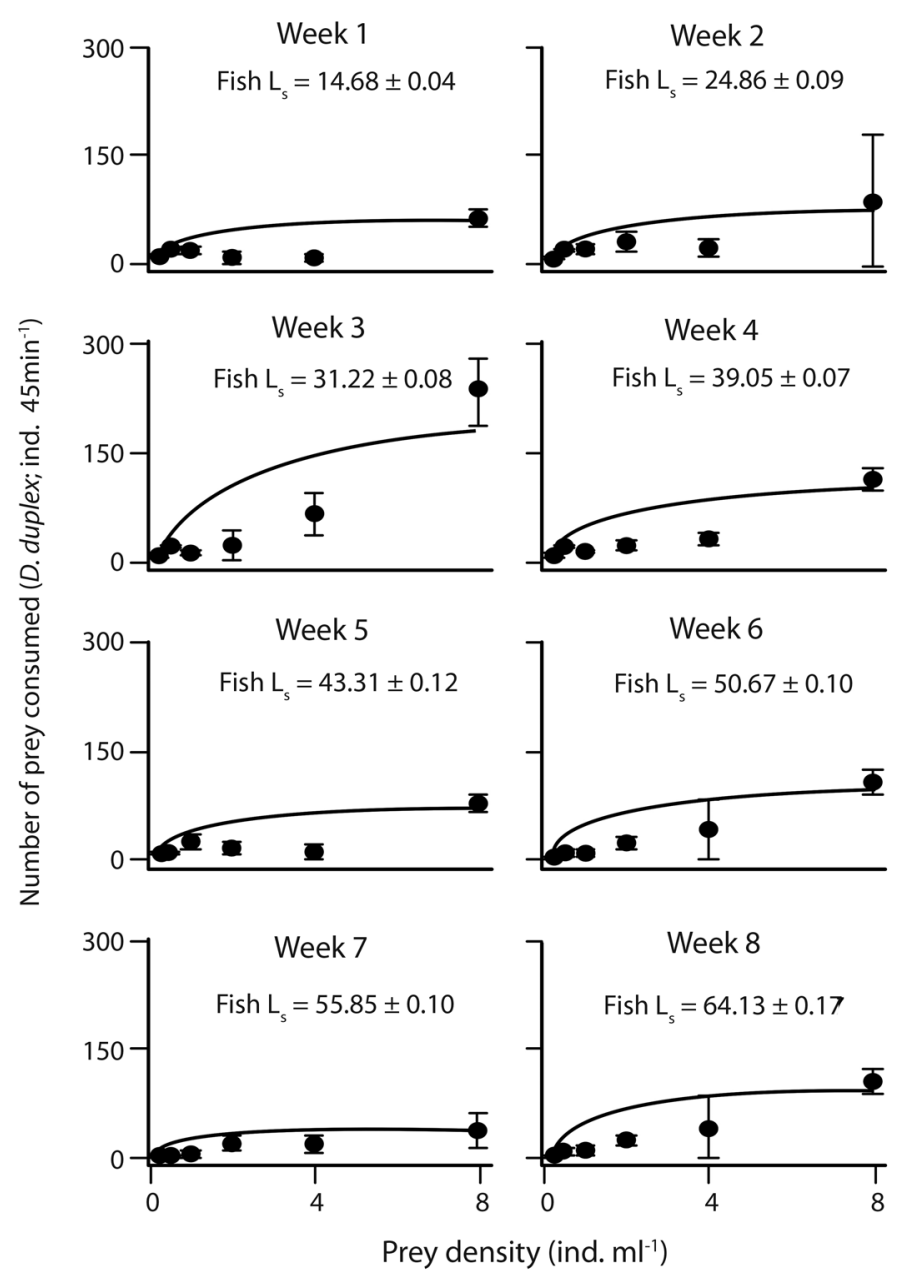

Fig. 2. Functional response of larval A. tropicus based on the model of Holling using D. pulex as prey. Each point represents the mean $\pm \mathrm{SE}$, and $\mathrm{L}_{\mathrm{s}}=$ fish standard length.

$(105 \pm 10.9)$ was higher than that for D. pulex $(100 \pm 20.85)$. However, the consumption of $A$. franciscana and $D$. pulex was similar during the first 4 weeks, but during the next weeks the consumption of $D$. pulex decreased in comparison to A. franciscana. The consumption of M. macrocopa was high during the 8 weeks; however no clear changes in the pattern of consumption were generated in relation to fish age when M. macrocopa was offered.

Prey selectivity: The counts in the vessels matched with the dissected guts ( \pm 2 ind.). The two-way ANOVA using Manly's $\alpha$ showed statistical differences among the prey species selected (excluding the 3 and 5 week). Overall, no statistical differences where shown among prey densities (Table 3 ); the $A$. franciscana was selected in the three different densities during the first 3 weeks of age; after the third week, this prey species was only selected in the 4-5 week at density ii. After the third week of age of the fish larvae, M. macrocopa are selected during the next weeks until the 8 week; $D$. pulex was rarely selected throughout the experiment (Fig. 4). 

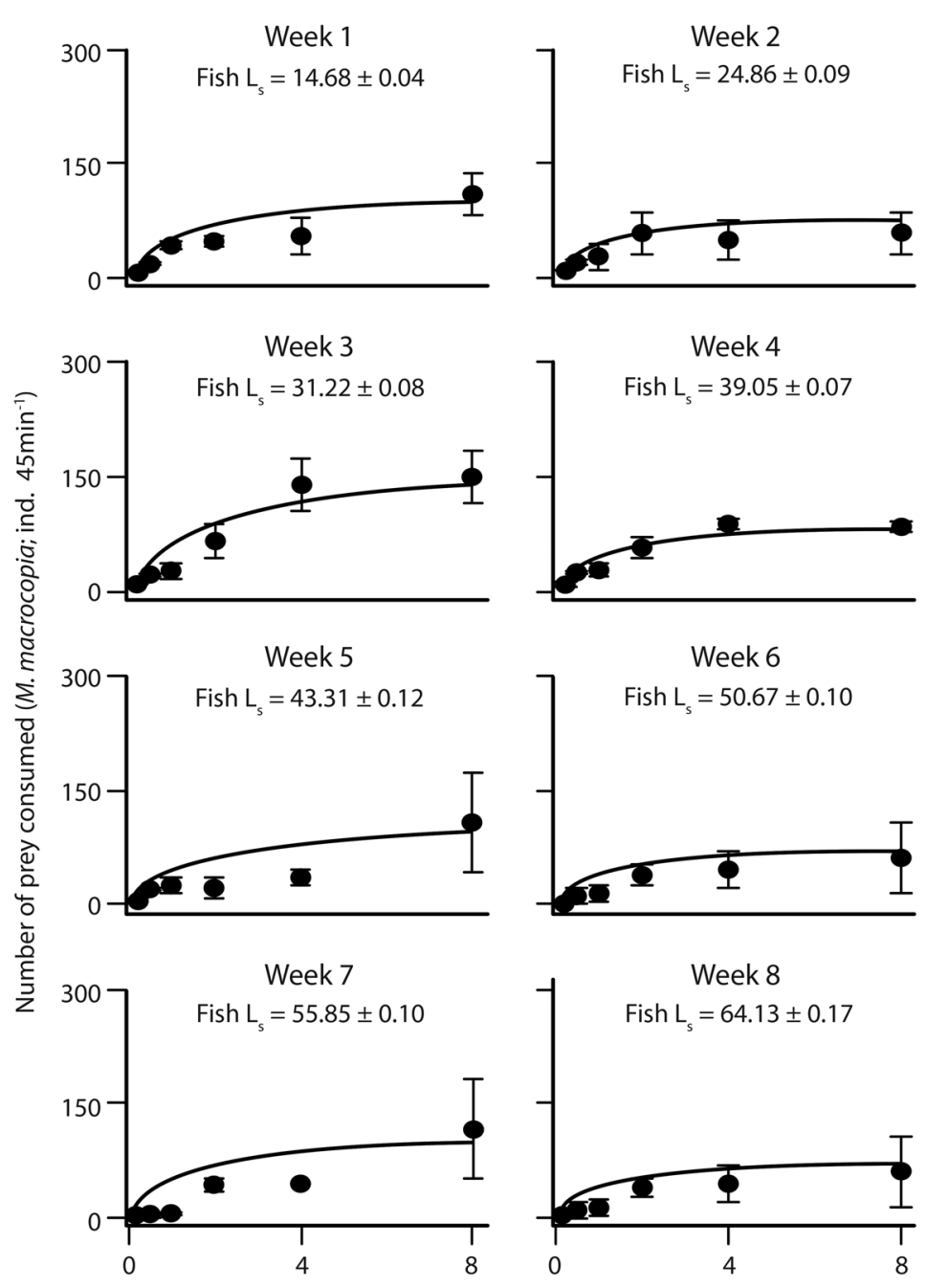

Prey density (ind. $\mathrm{ml}^{-1}$ )

Fig. 3. Functional response of larval A. tropicus based on the model of Holling using M. macrocopa as prey. Each point represents the mean $\pm \mathrm{SE}$, and $\mathrm{L}_{\mathrm{s}}=$ fish standard length.

Feeding behaviour: For the three different species of zooplankton, practically no rejection was registered and low escape values were found with $A$. fransiscana and $D$. pulex. Data on the increase of the $\mathrm{L}_{\mathrm{s}}, \mathrm{G}_{\mathrm{W}}$ and $\mathrm{G}_{\mathrm{L}}$ of $A$. tropicus during the first eight weeks of larval development showed a lineal relation (Fig. 5). Regardless of the larval age, prey species were hardly rejected by A. tropicus. The trends for both cladoceran prey species were nearly similar with respect to encounters but with a less number of encounters of these prey species compared with $A$. fransiscana. Attack, capture and ingestion patterns for M. macrocopa decreased when larval age increased, and in the last five weeks these events were statistically low. Values for encounters for $D$. pulex were lower than for A. fransiscana but higher than for M. macrocopa and they were relatively constant during the eight weeks. Attack, capture and ingestion values for cladocerans were the lowest of the three prey species and 
TABLE 2

$P$-value of the Slope, $\mathrm{F}_{\max }$ (mean $\pm \mathrm{SE}$ ), and $\mathrm{F}_{\text {max }}$ vs. asymptote $\mathrm{P}$-value regarding the functional response of $A$. tropicus using the three prey species

\begin{tabular}{|c|c|c|c|}
\hline Prey species/fish age (weeks) and $\mathrm{L}_{\mathrm{s}}$ & $P$-Slope & $\mathrm{F}_{\max }$ & $P-\mathrm{F}_{\max } v s$ asymptote \\
\hline \multicolumn{4}{|l|}{ A. franciscana } \\
\hline $1(14.68 \pm 0.04)$ & $-0.007 *$ & $59.75 \pm 3.87$ & 0.02 \\
\hline $2(24.86 \pm 0.09)$ & $-0.006^{*}$ & $87 \pm 6.29$ & 0.23 \\
\hline $3(31.22 \pm 0.08)$ & $-0.004 *$ & $212.25 \pm 30.28$ & 0.08 \\
\hline $4(39.05 \pm 0.07)$ & $-0.001^{*}$ & $148 \pm 2.80$ & 0 \\
\hline $5(43.31 \pm 0.12)$ & $-0.007^{*}$ & $117.75 \pm 7.56$ & 0.03 \\
\hline $6(50.67 \pm 0.10)$ & $-0.002 *$ & $52.66 \pm 8.31$ & 0.09 \\
\hline $7(55.85 \pm 0.10)$ & $0.000 *$ & $91.66 \pm 10.05$ & 0.04 \\
\hline $8(64.13 \pm 0.17)$ & $-0.002 *$ & $74 \pm 10.45$ & 0.15 \\
\hline \multicolumn{4}{|l|}{ D. pulex } \\
\hline $1(14.68 \pm 0.04)$ & $-0.002 *$ & $63.75 \pm 5.19$ & 0 \\
\hline $2(24.86 \pm 0.09)$ & $-0.002 *$ & $87 \pm 41.19$ & 0.44 \\
\hline $3(31.22 \pm 0.08)$ & $0.003 *$ & $234 \pm 20.32$ & 0 \\
\hline $4(39.05 \pm 0.07)$ & $-0.001 *$ & $113.75 \pm 7.18$ & 0 \\
\hline $5(43.31 \pm 0.12)$ & $-0.001 *$ & $77.33 \pm 5.22$ & 0 \\
\hline $6(50.67 \pm 0.10)$ & $0.001 *$ & $106.33 \pm 7.77$ & 0.01 \\
\hline $7(55.85 \pm 0.10)$ & $-0.002 *$ & $40.33 \pm 9.48$ & 0.34 \\
\hline $8(64.13 \pm 0.17)$ & $-0.003 *$ & $74 \pm 3.49$ & 0.01 \\
\hline \multicolumn{4}{|l|}{ M. macrocopa } \\
\hline $1(14.68 \pm 0.04)$ & $-0.004 *$ & $114 \pm 10.10$ & 0.01 \\
\hline $2(24.86 \pm 0.09)$ & $-0.007 *$ & $84 \pm 4.05$ & 0 \\
\hline $3(31.22 \pm 0.08)$ & $-0.004 *$ & $170.5 \pm 10.53$ & 0 \\
\hline $4(39.05 \pm 0.07)$ & $-0.006^{*}$ & $93 \pm 1.09$ & 0 \\
\hline $5(43.31 \pm 0.12)$ & $-0.001 *$ & $107.66 \pm 28.97$ & 0.25 \\
\hline $6(50.67 \pm 0.10)$ & $-0.003 *$ & $76.33 \pm 15.07$ & 0.25 \\
\hline $7(55.85 \pm 0.10)$ & $0.001 *$ & $117.66 \pm 29.18$ & 0.28 \\
\hline $8(64.13 \pm 0.17)$ & $-0.001 *$ & $73.66 \pm 3.38$ & 0.09 \\
\hline
\end{tabular}

Asterisk denotes $P$-value $<0.05$ for the slope. Values in parenthesis denotes the mean $\pm \mathrm{SE}$ of the Standard length $\left(\mathrm{L}_{\mathrm{s}}\right.$, in $\mathrm{mm}$ ) of the fish at the determined week of age Experiment was performed at $25.7^{\circ} \mathrm{C} \pm 0.02$.

were similar during the experiment (Table 4). Similar values obtained for the statistic $F$ in captures and ingestions confirm that $A$. tropicus presents a high rate of success in capture and ingest all prey species used in the present study.

\section{DISCUSSION}

The consumption of live food depends on prey species size and gape size and most fish larvae of commercial importance usually have a gape size $<200 \mu \mathrm{m}$ at early stages, restricting its diet to small prey, and fail to consume even the smaller cladocerans used in aquaculture such as Moina sp. and Ceriodaphnia sp. (Lubzens 1987; Khadka \& Rao, 1986; Villegas, 1990; Gerking, 1994). In comparison to other gar fish species, A. tropicus presents high growth rate after hatching (Comabella, Hurtado \& García-Galano, 2010); the smallest fish larvae at the first week of age used in the present study showed a $\mathrm{G}_{\mathrm{W}}$ of $1.0 \mathrm{~mm}$ and a $\mathrm{G}_{\mathrm{L}}$ of 1.3 $\mathrm{mm}$, and consumed preys of sizes that range 1500-1000 $\mu \mathrm{m}$, suggesting that the selectivity and feeding behaviour of this fish species could be related to the ability of handling prey 
TABLE 3

Two-way ANOVAs between densities and prey species obtained from Manly's alpha, considering A. tropicus larval age (weeks)

$\begin{array}{lcccc}\quad \begin{array}{c}\text { Source of } \\ \quad \text { Variation }\end{array} & \text { DF } & \text { SS } & \text { MS } & \text { F } \\ \text { Week 1 } & & & & \\ \text { Prey } & 2 & 0.04 & 0.02 & 10.829^{*} \mathrm{DM} \\ \text { Density } & 2 & 0 & 0 & 0.02 \\ \text { Prey x Density } & 4 & 0.05 & 0.01 & 6.858^{*}\end{array}$

\section{Week 2}

$\begin{array}{lcccc}\text { Prey } & 2 & 0.07 & 0.03 & 4.427 * \text { AD, DM } \\ \text { Density } & 2 & 0 & 0 & 0.004 \\ \text { Prey x Density } & 4 & 0.06 & 0.01 & 1.888\end{array}$

Week 3

$\begin{array}{lcccc}\text { Prey } & 2 & 0.02 & 0.01 & 1.649 \\ \text { Density } & 2 & 0 & 0 & 0.007 \\ \text { Prey x Density } & 4 & 0.02 & 0.01 & 1.172\end{array}$

Week 4

$\begin{array}{lcccc}\text { Prey } & 2 & 0.04 & 0.02 & 9.904^{*} \mathrm{DM} \\ \text { Density } & 2 & 0 & 0 & 0.146 \\ \text { Prey x Density } & 4 & 0.1 & 0.02 & 13.38^{*}\end{array}$

Week 5

$\begin{array}{lcccc}\text { Prey } & 2 & 0.02 & 0.01 & 2.387 \\ \text { Density } & 2 & 0 & 0 & 0.012 \\ \text { Prey x Density } & 4 & 0.01 & 0 & 0.591\end{array}$

Week 6

$\begin{array}{lcccc}\text { Prey } & 2 & 0.06 & 0.03 & 6.129 * \mathrm{AD} \\ \text { Density } & 2 & 0 & 0 & 0.012 \\ \text { Prey x Density } & 4 & 0.08 & 0.02 & 4.156^{*}\end{array}$

Week 7

$\begin{array}{lcccc}\text { Prey } & 2 & 0.21 & 0.1 & 44.981^{*} \text { AD, DM } \\ \text { Density } & 2 & 0 & 0 & 0.029 \\ \text { Prey x Density } & 4 & 0.03 & 0.01 & 2.909^{*}\end{array}$

\section{Week 8}

\begin{tabular}{lcccc} 
Prey & 2 & 0.1 & 0.05 & $21.943 *$ AD, DM \\
Density & 2 & 0 & 0 & 0.044 \\
Prey x Density & 4 & 0.03 & 0.01 & $3.53^{*}$ \\
\hline
\end{tabular}

Asterisk denotes $\mathrm{P}$-value $<0.05$ and the concatenate superscript letters $(\mathrm{A}=A$. fransiscana, $\mathrm{D}=D$. pulex and $M$ $=M$. macrocopa ) after the F-value, indicate no differences in pair comparisons (Tukey-Kramer HSD). Experiment was performed at $25.5^{\circ} \mathrm{C} \pm 0.03$. successfully in the predation process. As well, the common pattern in functional response of fish larvae is highly related to prey size (Puvanendran, Salies, Laurel, \& Brown, 2004; Peña-Aguado, Nandini, \& Sarma, 2009); therefore, our results from the functional response experiments support the hypothesis that in the wild A. tropicus is an active predator presenting a functional response of a carnivorous fish (Montenegro-Guillen, Vammen, \& Cisneros, 1991; Case, 1999; Jeschke, Kopp, \& Tollrian, 2002; Mendoza et al., 2008).

The lineal relation between body size and gape size observed in A. tropicus, suggests that the inclusion of larger prey and prey switching occurs in relation with fish larval age (Murdoch \& Bence 1987; Domínguez-Domínguez, Nandini, \& Sarma, 2002). Even when we did not find differences among the three densities used in selectivity experiments, after the third week, selectivity for $A$. fransiscana shifted to M. macrocopa. This result suggests that the switching for prey species in A. tropicus, could be more related to behavioural changes during later larval stages of the fish larvae than to conspicuous prey size (Zaret, 1980). Also, the shift in prey selection in A. tropicus indicates that even at low prey availability, the carnivorous fish larvae are able to manipulate and feed on zooplankton of wide range in size, in contrast with herbivore fish (e.g. C. carpio), where a very high initial density of zooplanktonic prey is required (Khadka \& Rao, 1986). Daphnia pulex was selected only in the $8^{\text {th }}$ week, and had the ability to escape once captured. This could be associated to the presence of morphological defence structures (e.g. apical spines, helmets); in contrast, $M$. macrocopa lacks these structures, which makes this prey species easier to manipulate for the fish larvae (Dodson \& Frey, 2001).

The ability of $A$. tropicus to manipulate prey at low densities is supported by the high capture success and high ratio of ingestion per capture, enhancing the larval survival. Our study indicates that A. tropicus larvae fed well on $M$. macrocopa and A. fransicana once the yolk was absorbed and until the first 
TABLE 4

Events of feeding behavior (mean $\pm \mathrm{SE}$ ) at the different larval age of $A$. tropicus using the three prey species

\begin{tabular}{|c|c|c|c|c|c|c|c|}
\hline Prey species & $\begin{array}{l}\text { Fish age } \\
\text { (weeks) }\end{array}$ & Encounters & Attacks & Captures & Ingestions & Rejections & Escapes \\
\hline \multirow{8}{*}{ A. franciscana } & 1 & $7.4 \pm 2.32$ & $0.8 \pm 0.49$ & $0 \pm 0$ & $0 \pm 0$ & $0 \pm 0$ & $0 \pm 0$ \\
\hline & 2 & $31.6 \pm 3.69$ & $10.8 \pm 3.05$ & $9.8 \pm 3.02$ & $9.8 \pm 3.02$ & $0 \pm 0$ & $2 \pm 0.32$ \\
\hline & 3 & $28.6 \pm 4.87$ & $7 \pm 2.61$ & $5.8 \pm 2.4$ & $5.8 \pm 2.4$ & $0 \pm 0$ & $1 \pm 0.32$ \\
\hline & 4 & $24.6 \pm 2.71$ & $1.8 \pm 1.2$ & $1 \pm 0.77$ & $1 \pm 0.77$ & $0 \pm 0$ & $1 \pm 0.63$ \\
\hline & 5 & $22.2 \pm 2.13$ & $3.6 \pm 1.17$ & $2.4 \pm 1.03$ & $2 \pm 1.14$ & $0 \pm 0$ & $1.2 \pm 0.38$ \\
\hline & 6 & $26.4 \pm 3.92$ & $2.6 \pm 0.93$ & $2.2 \pm 0.73$ & $2.2 \pm 0.73$ & $0 \pm 0$ & $0.4 \pm 0.25$ \\
\hline & 7 & $17.6 \pm 2.11$ & $1.6 \pm 0.68$ & $1.6 \pm 0.68$ & $1.4 \pm 0.51$ & $0.2 \pm 0.2$ & $0.2 \pm 0.2$ \\
\hline & 8 & $15.4 \pm 1.63$ & $2.2 \pm 0.58$ & $2.2 \pm 0.58$ & $2.2 \pm 0.58$ & $0 \pm 0$ & $0 \pm 0$ \\
\hline $\mathrm{F}_{7,40}$ & & $6.371 *$ & $4.51^{*}$ & $4.51^{*}$ & $4.58^{*}$ & 1 & $4.67 *$ \\
\hline \multirow{8}{*}{ D. pulex } & 1 & $8.8 \pm 2.06$ & $5 \pm 2.17$ & $4 \pm 2.51$ & $4 \pm 2.51$ & $0 \pm 0$ & $0 \pm 0$ \\
\hline & 2 & $11.2 \pm 2.75$ & $1.8 \pm 1.11$ & $1.4 \pm 1.17$ & $0.2 \pm 0.2$ & $0.2 \pm 0.2$ & $0.4 \pm 0.4$ \\
\hline & 3 & $13.2 \pm 3.18$ & $2.6 \pm 0.6$ & $1.2 \pm 0.38$ & $1.2 \pm 0.38$ & $0 \pm 0$ & $1.2 \pm 0.58$ \\
\hline & 4 & $7.4 \pm 2.2$ & $0.6 \pm 0.4$ & $0 \pm 0$ & $0 \pm 0$ & $0 \pm 0$ & $0.6 \pm 0.4$ \\
\hline & 5 & $17.4 \pm 3.99$ & $1.6 \pm 0.25$ & $1.2 \pm 0.2$ & $1.2 \pm 0.2$ & $0 \pm 0$ & $0.4 \pm 0.25$ \\
\hline & 6 & $21.2 \pm 1.53$ & $1 \pm 0.55$ & $1 \pm 0.55$ & $1 \pm 0.55$ & $0 \pm 0$ & $0 \pm 0$ \\
\hline & 7 & $13.6 \pm 1.81$ & $2.4 \pm 0.87$ & $1.8 \pm 0.58$ & $1.6 \pm 0.6$ & $0 \pm 0$ & $0.6 \pm 0.4$ \\
\hline & 8 & $12 \pm 0.71$ & $3.2 \pm 0.58$ & $2.6 \pm 0.51$ & $2.6 \pm 0.51$ & $0 \pm 0$ & $0.6 \pm 0.4$ \\
\hline $\mathrm{F}_{7,40}$ & & 1.13 & 1.95 & 1.31 & 1.81 & 1 & 1.13 \\
\hline \multirow{8}{*}{ M. macrocopa } & 1 & $18.6 \pm 2.09$ & $14.6 \pm 2.04$ & $11.6 \pm 2.18$ & $11.6 \pm 2.18$ & $0 \pm 0$ & $0 \pm 0$ \\
\hline & 2 & $21 \pm 4.81$ & $8.4 \pm 3.81$ & $7 \pm 3.45$ & $7 \pm 3.45$ & $0 \pm 0$ & $1.2 \pm 0.58$ \\
\hline & 3 & $9.6 \pm 2.07$ & $3.6 \pm 1.94$ & $3.6 \pm 1.94$ & $3.6 \pm 1.94$ & $0 \pm 0$ & $0.2 \pm 0.2$ \\
\hline & 4 & $6.6 \pm 0.87$ & $0 \pm 0$ & $0 \pm 0$ & $0 \pm 0$ & $0 \pm 0$ & $0 \pm 0$ \\
\hline & 5 & $11.2 \pm 3.1$ & $0.4 \pm 0.25$ & $0.2 \pm 0.2$ & $0.2 \pm 0.2$ & $0 \pm 0$ & $0.2 \pm 0.2$ \\
\hline & 6 & $17.8 \pm 4.59$ & $0 \pm 0$ & $0 \pm 0$ & $0 \pm 0$ & $0 \pm 0$ & $0 \pm 0$ \\
\hline & 7 & $10 \pm 1$ & $0 \pm 0$ & $0 \pm 0$ & $0 \pm 0$ & $0 \pm 0$ & $0 \pm 0$ \\
\hline & 8 & $6.8 \pm 1.24$ & $0.4 \pm 0.25$ & $0.4 \pm 0.25$ & $0.4 \pm 0.25$ & $0 \pm 0$ & $0 \pm 0$ \\
\hline $\mathrm{F}_{7,40}$ & & $3.84 *$ & $10.27^{*}$ & $7.33 *$ & $7.33 *$ & & $3.26^{*}$ \\
\hline \multicolumn{8}{|c|}{ pair-comparisons (Tukey-Kramer HSD) } \\
\hline \multicolumn{2}{|c|}{ A. franciscana - D. pulex } & $>0.05$ & 0.09 & 0.09 & 0.06 & 1 & 0.22 \\
\hline \multicolumn{2}{|c|}{ M. macrocopa-A. franciscana } & $>0.05$ & 0.86 & 0.91 & 0.95 & 0.66 & $>0.05$ \\
\hline \multicolumn{2}{|c|}{ M. macrocopa-D. pulex } & $>0.05$ & 0.26 & 0.2 & 0.12 & 0.66 & 0.18 \\
\hline
\end{tabular}

Asterisk denotes P-values $<0.05$ for the comparisons among larval age. At the bottom of the table, paired comparisons (Tukey-Kramer HSD) are shown. Experiment was performed at $25.8^{\circ} \mathrm{C} \pm 0.03$.

eight weeks of age. In general, rearing different freshwater larvae (e.g. fish, crustaceans) presents higher success in survivorship using a mix of zooplanktonic prey species (Gerking, 1994; Barros \& Valenti, 2003; Martín, et al., 2006). For A. tropicus Márquez-Couturier et al. (2006) obtained the higher survivorship using a mix of $D$. pulex and A. franciscana, and the lowest survivorship using $D$. pulex as the only food source. Considering the nutritional quality of these prey species; the percentage for protein and lipids of Daphnia sp. is 30.80 - 61.00 \% (Bogatova, Shcherbina, Ovinnikova, \& Tagirova, 1971) and $11.90-12.10 \%$ (Barata, Varo, Navarro, Arun \& Porte, 2005), for Moina sp. $69.53-75.20 \%$ and $9.94-11.51 \%$ and, Artemia sp. 59.06 and $16.77 \%$ (Alam, Ang, \& Chea, 1993) respectively; therefore, we suggest 

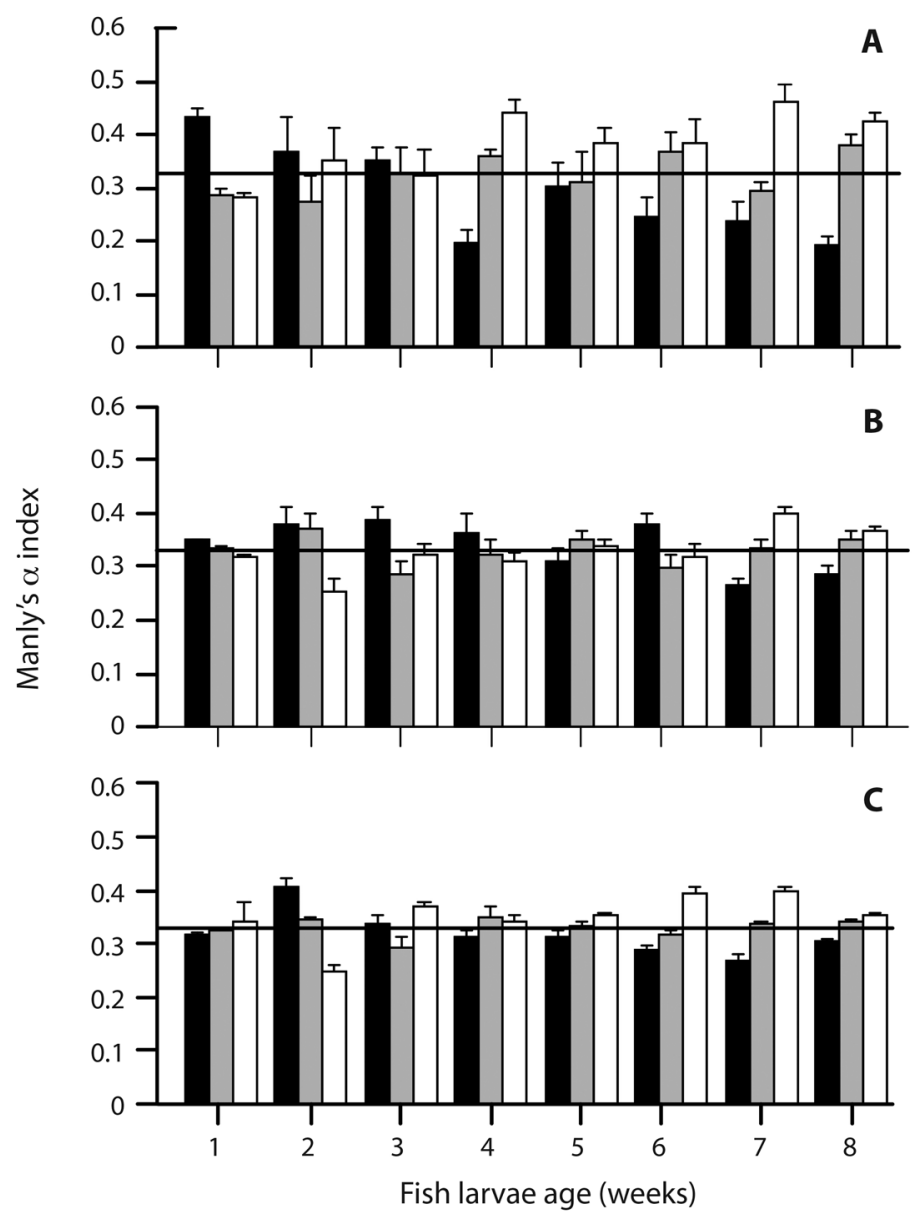

Fig. 4. Prey selection based on Manly's $\alpha$ using A. franciscana + D. pulex + M. macrocopa in a) $0.12+0.25+0.25$ ind. $\mathrm{mL}^{-1}$, b) $0.25+0.50+0.50$ ind. $\mathrm{mL}^{-1}$ and c) $0.5+1.0+1.0$ ind. $\mathrm{mL}^{-1}$, densities along the first eight weeks of the larval stage of $A$. tropicus. Bars represent mean $\pm \mathrm{SE}$, values above the horizontal line $(0.33)$ indicate positive selection.

that prey selection in A. tropicus could be related to the content of protein in the prey; however, the evaluation of the relation of the optimal nutritional requirements and fish behavior and selectivity for fish larvae is still needed.

Larval feeding studies of both ornamental and consumable fish species are important for formulating successful management, and culture strategies for conservation purposes. The zooplankton species used in this study can be cultured in high densities (Bossuyt \& Sorgeloos, 1979; Dodson \& Frey, 2001), and regarding its protein/lipids content and our results, we suggest the use of a mix of $A$. franciscana and M. macrocopa to feed A. tropicus in culture systems in concentrations $\approx 2$ ind. $\mathrm{mL}^{-1}$ during the first 3 weeks of age and then shift to M. macrocopa from the 4 week. The results obtained in this study can also be used in regional aquaculture for conservation efforts, enhancing this species growth at early stages and increasing the survivorship of adult and juvenile individual for further reintroduction or in situ management.

Directly, we did not test the survivorship of the larvae, however we used the three 

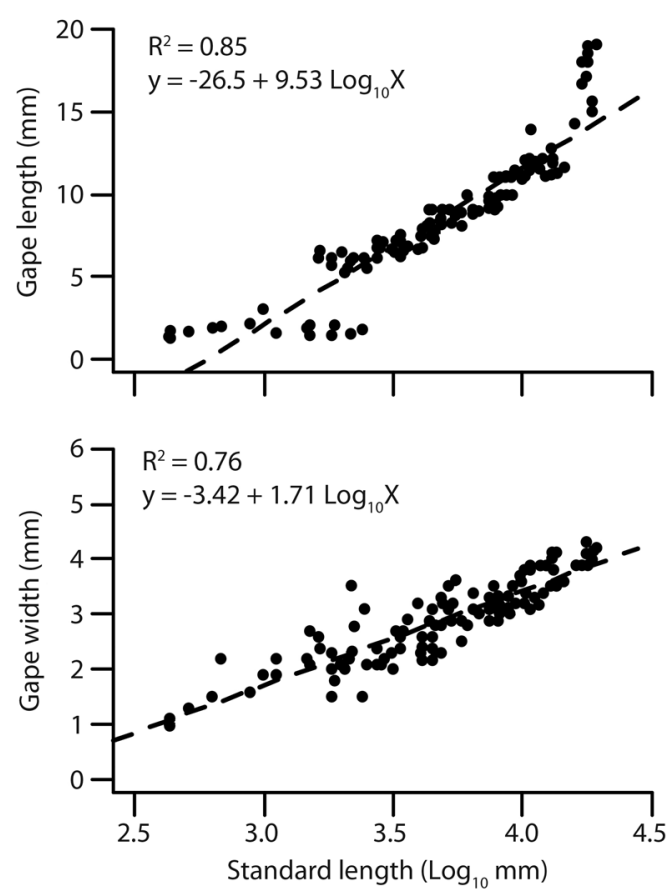

Fig. 5. Linear relation between gape length $\left(G_{L}\right.$; upper plot), gape width $\left(\mathrm{G}_{\mathrm{W}}\right.$; lower plot) with standard body length $\left(\mathrm{L}_{\mathrm{s}}\right)$.

zooplankton species in routine feeding of the larvae and obtained $92 \%$ of survivorship in the stocking density, suggesting that using a mix of these prey species can result in low fish larvae mortality. Our results, in conjunction with studies on the survivorship of the juveniles under natural conditions would aid in conservation efforts and improve the production of gars in aquaculture, mainly in North America, Central America and Cuba, where this species' populations have declined and are used for human consumption.

\section{ACKNOWLEDGMENTS}

The authors thank to the Hobbyist AquaLab Conservation Project in association with the Ark Mexican Project, Chester Zoo Garden and European Aquarist Associations for financial support. LHEV thanks to the National Council of Science and Technology CONACyT through the project number 264235 (Convocatoria I0027-2015-01). We thank to Karen Arias and Benjamin Villalobos for laboratory support and anonymous reviewers for their valuable comments and suggestions.

\section{RESUMEN}

Determinación de presas óptimas para la crianza del pejelagarto Atractosteus tropicus (Lepisosteiformes: Lepisosteidae). Estudios sobre alimentación en etapa larvaria en peces ornamentales como de consumo son importantes para formular estrategias exitosas de manejo y cultivo con fines de conservación. En el presente estudio evaluamos la selectividad de presa del pejelagarto Atractosteus tropicus en etapas larvarias (primeras 8 semanas) utilizando el zooplancton Artemia fransiscana, Daphnia pulex y Moina macrocopa como presas, probando la hipótesis de que la selección de presas en peces está relacionada no solamente a la preferencia por la especie de presa sino también a la diferencia en la densidad de presas en el ambiente. También se probó la respuesta funcional con densidades de presa de $0.2,0.5,1.0,2.0,4.0$ y 8.0 ind. $\mathrm{mL}^{-1}$. Para la selección de presa, utilizamos las tres especies de zooplancton en tres densidades diferentes. En ambos experimentos, las larvas de los peces se alimentaron por 45 min. Para cuantificar el comportamiento alimenticio (encuentros, ataques, capturas, ingestiones y rechazos), se usó una densidad de 1 ind. $\mathrm{mL}^{-1}$ utilizando cada especie de presa mediante observación directa por 10 minutos. Nuestros resultados muestran que $A$. tropicus presenta una respuesta funcional Tipo II, depredando principalmente $A$. franciscana y $M$. macrocopa. El índice $\alpha$ de Manly mostró que las especies M. macrocopa and A. franciscana fueron las mayormente seleccionadas. Los valores de encuentros para las tres especies de presa fueron relativamente constantes a lo largo de las ocho semanas. Los valores de ataque, captura e ingestión para los cladóceros fueron bajos; sin embargo, se observó gran éxito en la captura e ingestión para todas las especias de presa utilizadas. Nuestros resultados sobre los experimentos de respuesta funcional soportan la hipótesis de que A. tropicus es un depredador activo y presenta una respuesta funcional relacionada con especies de peces carnívoras y que el cambio en la selección de presas sugiere que aún a bajas densidades y disponibilidad de presas, $A$. tropicus es capaz de manipular y alimentarse de presas de diferentes tamaños. También, sugerimos el uso de una mezcla de $A$. franciscana y $M$. macrocopa para alimentar a A. tropicus en sistemas de cultivo en concentraciones $\approx 2$ ind. $\mathrm{mL}^{-1}$ durante las primeras tres semanas de edad y después cambiar a $M$. macrocopa a partir de la cuarta semana. Nuestros resultados, junto con estudios de sobrevivencia de los juveniles pueden ayudar a generar esfuerzos de conservación y mejorar la producción de pejelagarto en acuicultura. 
Palabras clave: pejelagarto; gaspar; presas plantónicas; respuesta funcional; selección de presa.

\section{REFERENCES}

Alam, M. J., Ang, K. J., \& Chea, S. H. (1993). Use of Moina micrura (Kurz) as an Artemia substitute in the production of Macrobrachium rosenbergii (de Man) post-larvae. Aquaculture, 109, 337-349.

Anonymous (1985). Methods of measuring the acute toxicity of effluents of freshwater and marine organisms. U.S. Environment Protection Agency EPA/600/485/0 13 .

Atencio-García, V. J., \& Zaniboni, F. E. (2006). El canibalismo en la larvicultura de peces. Revista $M V Z$ Córdoba, 11, 9-19.

Barata, C., Varo, I., Navarro, J. C., Arun, S., \& Porte, C. (2005), Antioxidant enzyme activities and lipid peroxidation in the freshwater cladoceran Daphnia magna exposed to redox cycling compounds. Comparative Biochemistry and Physiology, 140, 175-186.

Barros, H. P., \& Valenti, W. C. (2003). Ingestion rates of Artemia nauplii for different larval stages of Macrobrachium rosenbergii. Aquaculture, 217, 223-233.

Bogatova, I. B., Shcherbina, M. A., Ovinnikova, B. B., \& Tagirova, N. A. (1971). Chemical composition of some planktonic animals under different conditions of growing. Gidrobiologiceski Zurnal, 7, 54-57.

Bossuyt, E., \& Sorgeloos, P. (1979). Technological aspects of the batch culturing of Artemia in high densities. In G. Persoone, P. Sorgeloos, O. Roels, \& E. Jaspers (Eds.), The Brine Shrimp Artemia. Ecology, Culturing, Use in Aquaculture (Vol. 3, pp. 133- 152). Wetteren, Belgium: Universa Press.

Borowitzka, M. A., \& Borowitzka, L. J. (1988). MicroAlgal Biotechnology. London, UK: Cambridge University.

Case, T. J. (1999). An Illustrated Guide to Theoretical Ecology. New York, USA: Oxford University Press.

Colgan, P. W., Brown, J. A., \& Orsatti, S. D. (1986). Role of diet and experience in the development of foraging behavior in largemouth bass (Micropterus salmoides). Journal of Fish Biololy, 28, 161-170.

Comabella, Y., Hurtado, A., \& García-Galano, T. (2010) Ontogenetic changes in the morphology and morphometry of Cuban gar (Atractosteus tristoechus). Zoological Science, 27, 931-938.

Córdova-Tapia, F., Contreras, M., \& Zambrano, L. (2014). Trophic niche overlap between native and non-native fishes. Hidrobiologia, 746, 291-901.
Cunha, I., \& Planas, M. (1999). Optimal prey size for early turbot larvae (Scophthalmus maximus L.) based on mouth and ingested prey size. Aquaculture, 175, 103-110.

Dodson, S. I., \& Frey, D. G. (2001). Cladocera and other Branchiopoda. In J. H. Thorp \& A. P. Covich (Eds.), Ecology and classification of North American freshwater invertebrates (pp. 849-913). San Francisco, CA: Academic Press.

Domínguez-Domínguez, O., Nandini, S., \& Sarma, S. S. S. (2002). Larval feeding behaviour of the endangered fish golden bubblebee goodeid, Allotoca dugesi: implications for conservation of an endangered species. Fisheries Management and Ecology, 9, 285-291.

Domínguez-Domínguez, O., Pérez-Ponce de León, G., Martínez-Meyer, E., \& Zambrano, L. (2006). Using ecological-niche modeling as a conservation tool for freshwater species: Live-bearing fishes in central Mexico. Conservation Biology, 20, 1730-1739.

Dutta, H. M. (1996). A composite approach for evaluation of the effects of pesticides on fish (pp. 250-271). In J. S. D. Munshi \& H. M. Dutta (Eds.), Fish Morphology. New York, USA: Science Publishers Inc.

Gallardo-Alanis, J., Sarma, S. S. S., \& Nandini, S. (2009). Prey selectivity and functional response by larval redeyed tetra Moenkhausia Sanctaefilomenae (Steindachner, 1907) (Characiformes: Characidae). Brazilian Archives of Biology and Technology, 52, 1209-1216.

Gerking, S. D. (1994). Feeding Ecology of Fish. San Diego, USA: Academic Press.

Greene, C. H. (1983). Selective predation in freshwater zooplankton communities. Internationale Revue der gesamten Hydrobiologie und Hydrographie, 68, 297-315.

Holling, C. S. (1966). The functional response of invertebrate predators to prey density. Memoirs of the Entomological Society of Canada, 48, 1-86.

Jeschke, J. M., Kopp, M., \& Tollrian, R. (2002). Predator functional responses: discriminating between handling and digesting prey. Ecological Monographs, 72, 95-112.

Jhingran, V. G. (1991). Fish and Fisheries of India, revised and anlarged. Delhi, India: Hindustan Publishing Corporation.

Juanes, F. (1994). What determines prey size selectivity in piscivorous fishes?. In D. J. Stouder, K. L. Fresh, \& R. J. Feller (Eds.), Theory and application in fish feeding ecology (pp. 79-100). USA: University of South Carolina Press.

Katavic, I., Jug-Dujakovic, J., \& Glamuzina, B. (1989). Cannibalism as a factor affecting the survival of 
intensively cultured sea bass (Dicentrarchus labrax) fingerlings. Aquaculture, 77, 135-143.

Krebs, J. R., \& Davies, N. B. (1993). Behavioural Ecology. An Evolutionary Approach. London, UK: Wiley-Blackwell.

Khadka, R. B., \& Rao, T. R. (1986). Prey size selection by common carp (Cyprinus carpio var. communis) larvae in relation to age and prey density. Aquaculture, 88, 69-74.

Lampert, W., \& Sommer, U. (1997). Limnoecology. The ecology of lakes and streams. New York, USA: Oxford University Press.

Laurel, B. J., Brown, J. A., \& Anderson, R. (2001). Behaviour, growth and survival of redfish larvae in relation to prey availability. Journal of Fish Biology, 59, 884-901.

Lazarro, X. (1987). A review of planktivorous fishes: their evolutions, feeding behaviours, selectivities and impacts. Hydrobiologia, 146, 97-167.

Lubzens, E. (1987). Raising rotifers for use in aquaculture. Hydrobiologia, 147, 245-255.

Márquez-Couturier, G., Álvarez, C., Contreras, W., Hernández, U., Hernández, A. Mendoza R., Aguilera, C., García, T., Civera, R., \& Goytortua, E. (2006). Avances en la alimentación y nutrición de pejelagarto Atractosteus tropicus. In Memorias del VIII Simposium Internacional de Nutrición Acuícola (pp. 446523). Monterrey, México: UANL.

Martín, L., Arenal A., Fajardo, J., Pimentel, E., Hidalgo, L., Pacheco, M., García, C., \& Santiesteban, D. (2006). Complete and partial replacement of Artemia nauplii by Moina micrura during early postlarval culture of white shrimp (Litopenaeus schmitti). Aquaculture Nutrition, 12, 89-96.

Mendoza, A. R., Aguilera, G. C., \& Ferrara, A. M. (2008). Gar biology and culture: status and prospects. Aquaculture Research, 38, 748-763.

Mendoza, R., Aguilera, C., Rodriguez, G., González, M., \& Castro, R. (2002). Morphophysiological studies on alligator gar (Atractosteus spatula) larval development as a basis for their culture and repopulation of their natural habitats. Reviews in Fish Biology and Fisheries, 12, 33-142.

Montenegro-Guillen, S., Vammen, K., \& Cisneros, R. (1991). Biotic interactions in Lake Xolotlán (Managua): An integrating approach. Hydrobiological Bulletin, 25, 177-179.

Morales-Ventura, J., Nandini, S., \& Sarma, S. S. S. (2004). Functional responses during the early larval stages of the charal fish Chirostoma riojai (Pisces: Atherinidae) fed rotifers and cladocerans. Journal of Applied Ichthyology, 20, 417-421.
Murdoch, W. W., \& Bence, J. (1987). General predators and unstable prey populations. In W.C. Kerfoot \& A. Sih (Eds.), Predation: Direct and Indirect Impacts on Aquatic Communities (pp. 17-30). Hanover, USA: University Press of New England.

Nandini, S., \& Sarma, S. S. S. (2000). Zooplankton preference by two species of freshwater ornamental fish larvae. Journal of Applied Ichthyology, 16, 273-275.

Nguyen, H. Q., Reinertsen, H., Wold, P., Tran, T. M., \& Kjørsvik, E. (2010). Effects of early weaning strategies on growth, survival and digestive enzyme activities in cobia (Rachycentron canadum L.) larvae. Aquaculture International, 19, 63-78.

Peña-Aguado, F., Nandini, S., \& Sarma, S. S. S. (2009). Functional response of Ameca splendens (Family Goodeidae) fed cladocerans during the early larval stage. Aquaculture Research, 40, 1594-1604.

Puvanendran, V., Salies K., Laurel, B., \& Brown, J. A. (2004). Size-dependent foraging of larval Atlantic cod (Gadus morhua). Canadian Journal of Zoology, 82, 1380-1389.

R development Core Team (2014) R: A Language and Environment for Statistical Computing. R Foundation for Statistical Computing. Vienna, Austria. http:// www.R-project.org

Rao, T. R. (2003). Ecological and ethological perspectives in larval fish feeding. Journal of Applied Aquaculture, 13, 145-178.

Sarma, S. S. S., López-Rómulo, J. A., \& Nandini, S. (2003). Larval feeding behaviour of blind fish Astyanax fasciatus (Characidae), black tetra Gymnocorymbus ternetzi (Characidae) and angel fish Pterophyllum scalare (Cichlidae) fed zooplankton. Hydrobiologia, 510, 207-216.

Tapia, M. \& Zambrano, L. (2003). From aquaculture goal to real social and ecological impacts: carp introduction in rural central Mexico. AMBIO, 32, 252-257.

Tilseth, S. \& Ellertsen, B. (1984). Food consumption rate and gut evacuation processes of first feeding cod larvae (Gadus morhua L.). In E. Dahl, D. S. Danielssen, E. Moksness \& P. Solemdal (Eds.), The propagation of cod Gadus morhua L.: an international symposium, Arendal.

Trexler, J. C., McCulloch, C. E., \& Travis, J. (1988). How can the functional response best be determined? Oecologia, 76, 206-214.

Venables, W. N. \& Ripley, B. D. (2002). Modern Applied Statistics with $S$. New York, USA: Springer.

Villegas, C. T. (1990). The effects of growth and survival of feeding water fleas (Moina macrocopa Straus) and 
rotifers (Brachionus plicatilis) to milkfish (Chanos chanos Forsskal) fry. The Israeli Journal of Aquaculture-Bamidgeh, 42, 10-17.

Zambonino, J. L. \& Cahu, C. L. (2007). Dietary modulation of some digestive enzymes and metabolic processes in developing marine fish: applications to diet formulation. Aquaculture, 268, 98-105.
Zambrano, L., Perrow, M., Aguirre-Hidalgo, V., \& MacíasGarcía, C. (1999). Impact of introduced carp (Cyprinus carpio) in subtropical shallow ponds in central Mexico. Journal of Aquatic Ecosystems Stress and Recovery, 6, 281-288.

Zaret, T. M. (1980). Predation and freshwater communities. New Haven, CT, USA: Yale University Press. 